\title{
AKUISISI TANAH-TANAH RAKYAT: PROBLEM HGU PT. BMS DI REJANG LEBONG DAN JALAN PENYELESAIANNYA Rezky Dellah R. ${ }^{\text {\& M M }}$. Nazir Salim²
}

\begin{abstract}
In 1988, PT. BMS Aceuired Cultivation Rights Title (CRT/HGU) for 6.925 acres in Kabupaten Rejang Lebong. The land aceuisition process after CRT has been given through land relinquishment, however PT. BMS only able to relineuish people's land for 2.046 acres. This condition caused uncertainty of land rights upon community. Later on, the condition caused overlapping of land ownership and authorization of PT. BMS CRT, ended by the reclaiming and cancellation upon the land right. Formal legal perspective and descriptive analytic study describe several issues related to the constraints of the right and status of land for the farmers. This study found some fundamental issues, first related to objects of CRT as state land. Legally, it was considered flawed because the company only released less than half of the rights, triggering reclaimings by the residents who assumed that it was their land. Therefore, the state should seek ways to strengthen the rights of peasants with the scheme of redistribution or the reinforcement of the right to avoid land right conflicts. This review offers main alternative policy solution scheme: Redistribution, the granting of a Right License, or a plasma core plantation scheme. Keywords: HGU PT BMS, cultivator farmers, and policy alternatives.

Intisari: Pada tahun 1988, PT BMS memperoleh Hak Guna Usaha seluas 6.925 Ha di Kabupaten Rejang Lebong. Proses perolehan tanah HGU-nya lewat pembebasan lahan masyarakat, namun PT BMS hanya mampu membebaskan tanah masyarakat 2.046 Ha sehingga menimbulkan ketidakpastian hak atas tanah masyarakat. Kondisi tersebut kemudian mengakibatkan terjadinya tumpang tindih pemilikan dan penguasaan tanah pada areal HGU PT BMS yang berakhir dengan reklaiming dan pembatalan hak atas tanah. Perspektif legal formal dan deskriptif analitis kajian ini menjelaskan beberapa hal terkait kendala kedudukan hak dan status bagi petani penggarap. Kajian ini menemukan beberapa hal mendasar, pertama terkait obyek HGU sebagai tanah negara yang cacat hukum karena perusahaan hanya membebaskan kurang dari separo hak yang diberikan, sehingga menimbulkan gelombang reklaiming oleh warga yang merasa lahan tersebut adalah miliknya. Oleh karena itu, negara semestinya berupaya memberikan penguatan hak bagi petani penggarap dengan skema redis atau penguatan hak untuk menghindari konflik ketidakpastian hak garapannya. Kajian ini menawarkan skema solusi alternatif kebijakan utamanya: Redistribusi, pemberian Surat Izin Hak Garap, atau skema perkebunan inti plasma.
\end{abstract}

Kata kunci: HGU PT BMS, petani penggarap, dan alternatif kebijakan.

\section{A. Pendahuluan}

Sejak zaman Orde Baru, pemerintah melalui kebijakannya membuka peluang yang sebesarnyabesarnya kepada pemilik modal untuk menguasai dan memiliki tanah rakyat dengan pertimbangan demi kepentingan pertumbuhan ekonomi, sehingga terjadi pergeseran kedudukan tanah dari

r Staf Kanwil ATR/BPN Provinsi Bengkulu. Email: ecky.sasmita@gmail.com

2. Staf Pengajar Sekolah Tinggi Pertanahan Nasional. Email: azet_r@yahoo.com fungsi sosial menjadi fungsi komoditas.

Pemerintah menerapkan kebijakan pertanahan yang mampu mendukung pertumbuhan ekonomi dan menggiring investor ke lokasi-lokasi yang selama ini kurang mendapat minat untuk dikembangkan secara maksimal. Kebijakan pertanahan tersebut salah satunya adalah pemberian Hak Guna Usaha (HGU) perkebunan kepada korporasi. Berdasarkan data yang ada, sejak tahun 1980-2014 tercatat jumlah HGU perkebunan swasta di Indonesia sebanyak 2.676 bidang dengan total luasan 
16.338.414 Ha (Marbun 2015).

Kecenderungan pemerintah berpihak pada kepentingan investor khususnya di bidang usaha perkebunan menyebabkan akses rakyat terhadap tanah semakin berkurang. Di Kalimantan Barat yang didominasi oleh wilayah hutan, distribusi penguasaannya (Hak Pengusahaan Hutan (HPH), Hutan Tanaman Industri (HTI), perkebunan, transmigrasi, dan lain-lain) seringkali berakibat terhadap pengurangan akses masyarakat setempat terhadap tanah (Sumardjono, 2008:30). Hal tersebut juga terjadi di Provinsi Bengkulu, pembangunan perkebunan menjadi salah satu sub sektor yang menempati prioritas utama dalam pola dasar pembangunan daerah. Memasuki Pelita III (1979), langkah awal untuk memacu pengembangan perkebunan di Provinsi Bengkulu adalah dengan dikeluarkannya Surat Keputusan Gubernur Kepala Daerah Tingkat I Bengkulu Nomor 241 Tahun 1983 yang berisi program pencadangan tanah seluas 400.0oo ha untuk pengembangan perkebunan (Komunikasi dengan Supriyadi, 2016). Dari tanah seluas 400.oo Ha yang dicadangkan sampai pertengahan tahun 1988 sudah tersalurkan untuk perkebunan \pm 245.0oo Ha kepada 73 perusahaan terutama untuk tanaman karet, kelapa sawit, dan coklat (Memori Serah Terima Jabatan Gubernur Bengkulu 1984 s/ d 1989, 113).

Salah satu perusahaan yang menanamkan modalnya untuk usaha perkebunan di Provinsi Bengkulu adalah PT. Bumi Megah Sentosa (PT. BMS). PT. BMS diberikan HGU berdasarkan SK Menteri Dalam Negeri Nomor 03/HGU/1988 tanggal 12 Februari 1988 dengan jangka waktu 30 tahun atas tanah seluas 6.925 Ha untuk perkebunan coklat. Pemberian HGU kepada PT. BMS telah menyebabkan masyarakat kehilangan akses terhadap tanah pertanian dan kehilangan sumber pencaharian untuk memenuhi kebutuhan hidup karena tanah yang diberikan HGU tersebut meskipun berasal dari tanah yang dicadangkan untuk perkebunan besar namun tanah tersebut bukan merupakan tanah negara melainkan tanah para petani yang merupakan masyarakat Suku Tengah Kepungut. ${ }^{3}$ Faktanya, PT. BMS hanya mampu membebaskan tanah seluas 2.046 Ha dari luas $6.925 \mathrm{Ha}$, terkendala dalam pemberian ganti rugi (Komunikasi dengan Zulkarnain, Mantan Kasi, Kakan, dan Kabid).

Permasalahan tumpang tindih "pemilikan" tanah yang tidak terselesaikan menyebabkan PT. BMS tidak dapat melakukan aktivitas perkebunan secara optimal. Seiring berjalannya waktu, pada tahun 1994 PT. BMS mengalami kebangkrutan dan meninggalkan tanah tersebut sehingga tanah terbengkalai dan menjadi semak belukar (Komunikasi dengan Mantan Karyawan Perkebunan PT. BMS 2016). Dibuktikan dengan adanya hasil penilaian berdasarkan klasifikasi perkebunan ${ }^{4}$ yang bertujuan untuk mengetahui kinerja yang dicapai oleh perusahaan terutama yang menyangkut aspek teknis, manajemen, dan kepatuhan perusahaan (Komunikasi dengan Maulitha, Kasi

${ }^{3}$ Suku Tengah Kepungut adalah salah satu komunitas adat yang berada di wilayah Administratif Kabupaten Rejang Lebong, Provinsi Bengkulu, secara administratif masuk ke dalam wilayah Kecamatan Kota Padang, secara historis merupakan kesatuan suku Bangsa Lembak dan berada di sepanjang DAS Hulu Musi dengan pola kelembagan adat dengan sistem marga yang di dasari atas dasar geneologis dan teritorial dan di kepalai oleh Pasirah. Sistem kelembagaan adat ini mengacu pada pola kekeluargaan yang timbul dari sistem unilateral dan garis keturunan yang patrilineal dan dengan cara perkawinan yang eksogami, namun kemudian sistem Kelembagaan Adat Lokal yang disebut dengan marga dihapus melalui UU No 5 Tahun 1979 tentang Pemerintahan Desa.

${ }^{4}$ Klasifikasi perusahaan perkebunan merupakan salah satu bentuk pembinaan yang dilakukan oleh Direktorat Jenderal Perkebunan terhadap pengelolaan usaha perkebunan yang dilaksanakan secara berkala setiap 3 (tiga) tahun sekali. Klasifikasi ini diperlukan untuk memperoleh data/informasi kebun dalam rangka pembinaan terhadap perusahaan perkebunan besar yang meliputi berbagai subsistem yaitu sub sistem manajemen, kebun, pengolahan hasil sosial ekonomi, dan lingkungan. 
Perizinan dan Pengawasan Perkebunan Besar Swasta Dinas Perkebunan Prov. Bengkulu 2016).

Berdasarkan hasil klasifikasi, PT. BMS masuk dalam kategori kebun kelas V (kebun terlantar), kriteria perkebunan terlantar menurut Dinas Perkebunan adalah tanaman perkebunan di atas tanah HGU yang tidak dipelihara dengan baik sesuai dengan pembinaan/teknis pertanian/ perkebunan, sesuai Pasal 3 Peraturan Pemerintah Nomor 36 Tahun 1998 tentang Penertiban dan Pendayagunaan Tanah Terlantar, yang berbunyi:

\section{Tanah Hak Milik, Hak Guna Usaha, Hak Guna Bangunan atau Hak Pakai dapat dinyatakan sebagai tanah terlantar apabila tanah tersebut dengan sengaja tidak dipergunakan oleh pemegang haknya sesuai dengan keadaannya atau sifat dan tujuan haknya atau tidak dipelihara dengan baik.}

Tanah perkebunan yang ditelantarkan inilah kemudian digarap oleh masyarakat dengan berkebun kopi dan karet. Petani menduduki dan mengolah tanah terlantar untuk memperoleh kehidupan yang layak karena tanah perkebunan terlantar sebelumnya merupakan tanah untuk menunjang kehidupan mereka. Berdasarkan data yang dirilis oleh NGO Akar Bengkulu, pada tahun 2013 ada sekitar 414 KK atau kurang lebih 1,678 jiwa, yang hidup dari budidaya perkebunan tersebut (Bahanan 2016).

Terkait dengan banyaknya penelantaran HGU oleh pemegang hak, analisis Anton Lucas dan C. Warren sebagaimana dikutip Salim menarik untuk dilihat. Munculnya kebijakan besar-besaran pada zaman Orde Baru yang dikeluarkan oleh BPN dengan mengeluarkan izin lokasi dan pemberian HGU pada akhirnya tanah-tanah itu tidak digunakan atau ditelantarkan, bahkan, banyak di antara mereka kemudian mengagunkan hak konsesinya (HGU) ke bank, namun setelah mendapatkan uang yang cukup besar mereka tidak mengolah atau menelantarkan tanahnya (Salim 2014).

Persis dugaan Anton Lucas, PT. BMS pada tahun 1988 mengagunkan sertipikat HGU-nya pada Bank
Dagang Negara dan mendapatkan pinjaman uang Rp. 14.000.000.000,00. Namun, modal yang dimiliki oleh PT. BMS yang berasal dari pinjaman bank tidak digunakan untuk melakukan usaha perkebunan di Rejang Lebong melainkan untuk usaha perkebunan lainnya di Jambi sejak tahun 1991 (Komunikasi dengan Zulkarnain 2016). Tanahyang seharusnya dapat mendatangkan kemakmuran tidak dimanfaatkan secara optimal, sehingga menimbulkan konflik kebutuhan atas tanah.

Hampir 80\% penduduk Kecamatan Kota Padang bermata pencaharian di sektor pertanian, yang didominasi sekitar $60 \%$ penduduknya berpenghasilan rendah dengan kepemilikan tanah pertanian yang sangat kecil, kurang dari 1 Ha (Komunikasi dengan Prayitno, Kasie Kesejahteraan Sosial Dinas Sosial 2016). Keterbatasan pemilikan lahan merupakan salah satu faktor adanya kecenderungan masyarakat yang tidak memiliki lahan untuk memanfaatkan tanah terlantar milik PT. BMS.

Atas situasi kebun di atas, Direktur Jenderal Perkebunan setelah menerima laporan dari Kepala Dinas Perkebunan Provinsi Bengkulu, atas nama Menteri Pertanian mengusulkan kepada Kepala Badan Pertanahan Nasional (BPN) untuk membatalkan HGU PT. BMS, demikian juga, Gubernur Provinsi Bengkulu mengusulkan pembatalan HGU PT. BMS. Pada tanggal 2 Juni 2000 HGU PT. BMS dicabut berdasarkan SK Kepala Badan Pertanahan Nasional No. 11-VIII/200o tentang Pembatalan HGU dan Pencabutan Surat Keputusan Pemberian HGU Atas Tanah terletak di Provinsi Bengkulu. Pembatalan terhadap HGU PT. BMS adalah akibat dari tanah tidak diusahakan sesuai dengan peruntukannya, pada Diktum Pertama keputusan tersebut menyatakan sebagai berikut:

\footnotetext{
Membatalkan Hak Guna Usaha sebagaimana tersebut dalam Lampiran Keputusan ini, atas tanah yang terletak di Propinsi Bengkulu dan menyatakan sertipikatsertipikat tersebut tidak berlaku lagi sebagai tanda bukti hak yang sah serta tanahnya menjadi tanah yang langsung dikuasai oleh negara (SK Kepala BPN No. 1 I VIII/2000).
} 
Berdasarkan SK Kepala BPN di atas, tanah milik PT. BMS yang dilekati HGU, sekarang statusnya berubah menjadi tanah yang dikuasai langsung oleh negara, kebijakan mengenai tanah negara bekas HGU PT. BMS yang diduduki oleh masyarakat diperlukan pengaturan terhadap aspek fisik penggunaan tanah dan aspek hukum penguasaan tanahnya. Kebijakan apa yang seharusnya diambil dan bagaimana praktiknya di lapangan akan dilihat secara komprehensif dalam analisis berikutnya. Lebih jauh kajian ini ingin melihat secara detil persoalan tersebut dalam konteks rumusan kebijakan dengan lebih dulu melihat mengapa masyarakat melakukan penggarapan terhadap tanah negara bekas HGU, bagaimana mekanisme penguatannya, dan apa yang menjadi kendala jika penguatan hak diberikan kepada petani penggarap.

Sejauh penelusuran penulis, belum ditemukan pihak-pihak yang meneliti kasus HGU PT. BMS dan solusi penyelesaiannya, namun demikian, penulis menemukan banyak studi yang mirip sebagai pembanding untuk melihat model, pendekatan, dan metode. Beberapa studi terkait di antaranya adalah Silvana (2002), Sanusi (1998), Suhariningsih dkk, (2008), Gunawan (2013) yang masing-masing mengangkat tema terkait problem tanah bekas hak atau tanah negara atau tanah-tanah yang dipertentangkan klaimnya. Beberapa kajian tersebut dapat menjadi model atau rujukan dalam membangun kerangka pemikiran meskipun terdapat perbedaan baik konsep maupun kasus dengan kajian yang penulis lakukan. Ada beberapa hal yang cukup menarik untuk dilihat lebih jauh, misalnya ada banyak tanah yang bisa diredistribusikan kepada petani melalui program pembaharuan agraria nasional, namun hanya satu obyek redistribusi tanah yang diatur, yaitu tanah negara bekas hak (tanah terlantar) lewat PP No. 11 Tahun 2010 tentang Penertiban dan Pendayagunaan Tanah Terlantar, sedangkan obyek-obyek lain belum diatur secara memadai, mengakibatkan memicu banyak persoalan di lapangan.
Pasal 4 ayat (1) UUPA menyatakan bahwa hak atas tanah adalah hakyang diberikan dan dipunyai orang-orang, baik sendiri-sendiri maupun bersamasama dengan orang lain. Menurut Soesangobeng, hak milik dalam teori hukum Romawi, lahir berdasarkan suatu proses pertumbuhan yang dimulai dari pendudukan dan penguasaan nyata (occupare de facto) untuk sampai pada pengakuan hukum (de jure) melalui keputusan (decisio) pemerintah (Soesangobeng 2012, 16-17). Pada awal penguasaan 'defacto"itu, orang diakui memiliki hak kepunyaan (jus possessionis), ${ }^{5}$ setelah dikuasai cukup lama tanpa sengketa maka pemegang hak kepunyaan mendapatkan pengakuan hukum yang lebih kuat dari pemerintah berupa keputusan pejabat negara yang sah, maka kekuatan hukum dari hak kepunyaan berubah menjadi hak milik sebagai hak pribadi atau privat yang tertinggi, sempurna, dan mutlak (Soesangobeng 2012). Terkait hal tersebut, penguatan hak atas tanah bagi petani penggarap sejalan dengan ketentuan dalam Pasal 13 ayat (4) UUPAyang bertujuan memberikan jaminan kepastian perolehan tanah garapan dan jaminan sosial bagi buruh tani (Erwiningsih 2009, 221).

Pola pemanfaatan dan penguasaan tanah tanpa alas hak oleh masyarakat khususnya petani penggarap sering terjadi pada tanah-tanah perkebunan terlantar yang dilekati HGU maupun atas tanah negara bekas hak lainnya, seperti yang terjadi di Kabupaten Rejang Lebong, petani penggarap memanfaatkan tanah bekas HGU PT. BMS sejak tanah tersebut masih dilekati HGU (tahun 1997), sampai dengan menjadi tanah negara, karena ada pembatalan hak. Menurut Boedi Harsono, tanah negara adalah bidang-bidang tanah yang dikuasai langsung oleh negara, meski tanah tersebut dikuasai oleh negara namun perlu digarisbawahi bahwa negara hanya menguasai bukan memiliki tanah. Hak menguasai negara atas tanah memiliki arti

${ }^{5}$ Hak kepunyaan adalah hak yang melekat pada subyek dari penguasaan fisik yang diakui oleh masyarakat sekitarnya. 
strategis terhadap perwujudan kesejahteraan rakyat, dilihat dari sudut pandang kebutuhan hidup secara ekonomi, pemenuhan atas hak-haknya dan perlindungan keamanananya (Erwiningsih 2009, 291-292). Dalam ranah itulah kajian ini akan melihat persoalan kasus HGU PT. BMS yang dikerangkai dengan menempatkan masyarakat sebagai pihak yang layak diberikan ruang secara luas untuk memperoleh (kembali) hak-haknya.

\section{B. Rejang Lebong: HGU dan Kemiskinan}

Luas wilayah Kabupaten Rejang Lebong adalah 151.576 Ha, sebagian terbesar dari wilayahnya terletak pada ketinggian di atas 1.000 m.dpl yaitu seluas 67.973 Ha atau 44,84\% dari luas wilayah dengan topografi wilayah bergelombang hingga berbukit, bahkan bergunung, dan memiliki udara yang sejuk. Kabupaten Rejang Lebong terdiri atas 15 kecamatan, 34 kelurahan, dan 122 desa.

Wilayah Kecamatan Kota Padang yang menjadi objek kajian ini berada di urutan terbesar ketiga dalam tingkatan luas wilayah yaitu seluas 17.229 Ha, Kecamatan Kota Padang teletak paling timur dari bagian wilayah administrasi Kabupaten Rejang Lebong dan berbatasan langsung dengan Provinsi Sumatera Selatan. Kecamatan Kota Padang terdiriatas 10 desa yakni: Durian Mas 2.438 Ha; Lubuk Mumpo 4.624 Ha; Dusun Baru 1.273 Ha; Bedeng Ss 813 Ha; Kota Padang 1.983 Ha; Suka Rami 848 Ha; Taba Anyar 732 Ha; Derati 1.o11; Kota Padang Baru 1.134 Ha; dan Tanjung Gelang 2.373 Ha (BPS Kota Padang 2015).

Berdasarkan data BPS tahun 2014 jumlah penduduk Kabupaten Rejang Lebong adalah 254.583 jiwa dengan rincian pendudukyang berjenis kelamin laki-laki sebesar 129.006 orang, sedangkan yang perempuan adalah 125.577 orang dengan luas wilayah sekitar $1.515,76 \mathrm{~km}^{2}$, maka rata-rata setiap $\mathrm{km}^{2}$ ditempati penduduk sebanyak 168 jiwa. Kecamatan dengan jumlah penduduk terpadat adalah Kecamatan Curupyaitu 8.oo3 penduduk per $\mathrm{km}^{2}$, Sementara Kecamatan Kota Padang yang menjadi objek kajian ini dimana salah satu wilayah
HGU berada luasnya 172,29 $\mathrm{km}^{2}$ dengan jumlah penduduk 12.250 jiwa dengan rata-rata penduduk perkilometer71,10 km² (BPS Kab. Rejang Lebong 2015).

Mata pencaharian penduduk suatu wilayah merupakan gambaran dariaktivitas keseharianyang dilakukan oleh masyarakat setempat, mata pencaharian penduduk relatif bervariasi terutama di perkotaan, sedangkan wilayah pedesaan sebagian besar penduduknya menggantungkan hidup pada sektor pertanian, dengan pola perkebunan, dan petanian palawija. Pada umumnya penduduk Rejang Lebong menggantungkan hidupnya pada sektor pertanian, dengan pola perkebunan (petani kopi) dan petani palawija seperti kubis, kentang, terong, ketimun, kacang dan, lainnya, oleh sebab itu roda perekonomian yang berkaitan dengan daya beli masyarakat sangat tergantung pada musim panen.

Salah satunya dapat dilihat pada penduduk Kecamatan Kota Padang, dimana terdapat sekitar \pm 2.185 rumah tangga pertanian, ${ }^{6}$ dengan jumlah anggota keluarga \pm 10.320 orang (BPS Kab. Rejang Lebong, 2014), terutama dalam bidang perkebunan, yaitu perkebunan karet dan kopi, disusul pada bidang pertanian tanaman pangan dan tanaman palawija, berupa jagung, ubi kayu, ubi jalar, kacang tanah, kedelai, kacang hijau (BPS Kab. Rejang Lebong 2015).

Mayoritas penduduk bermata pencaharian di sektor pertanian, namun didominasi sekitar 2.183 rumah tangga pertanian berpenghasilan rendah, dengan kepemilikan tanah pertanian yang sangat kecil (kurang dari $1 \mathrm{Ha}$ ), dengan rincian sebagai berikut:

Tabel 1 Jumlah Rumah Tangga Usaha Pertanian Menurut Luas Lahan yang Dikuasai.

\begin{tabular}{|c|c|c|}
\hline No. & Luas Lahan yang Dikuasai (Ha) & $\begin{array}{c}\text { Jumlah Rumah Tangga Usaha } \\
\text { Pertanian }\end{array}$ \\
\hline 1. & $=0.1$ & 1.773 \\
\hline 2. & $0.1-0.19$ & 28 \\
\hline 3. & $0.20-0.49$ & 186 \\
\hline 4. & $0.55-0.99$ & 151 \\
\hline \multicolumn{2}{|r|}{ Jumlah } & 2.183 \\
\hline
\end{tabular}

Sumber: BPS, Sensus Pertanian 2013, Hasil Pencacahan Lengkap Kabupaten Rejang Lebong.

${ }^{6}$ Adalah rumah tangga yang salah satu atau lebih anggota rumah tangganya mengelola usaha pertanian. 
Sempitnya luas lahan yang dimiliki tersebut sangat mempengaruhi penghasilan keluarga. Sebagaimana pendapat beberapa petani penggarap bahwasanya hasil usaha pertanian tersebut terkadang hanya cukup untuk dikonsumsi sendiri tanpa dijual kepada pihak lain, sehingga masyarakat masih sulit untuk memenuhi kebutuhan hidup lainnya. Data BPS menunjukkan, rata-rata pengeluaran per kapita sebulan penduduk di Kabupaten Rejang Lebong adalah sebesar Rp. 602.733, pengeluaran yang digunakan untuk kelompok makanan adalah sebesar Rp.350.939, sedangkan pengeluaran yang digunakan untuk kelompok non makanan adalah sebesar Rp.251.794 (BPS Kab. Rejang Lebong 2015, 14).

Keterbatasan pemilikan tanah merupakan salah satu faktoradanya kecenderungan masyarakat yang tidak memiliki lahan untuk memanfaatkan tanah terlantar milik PT. BMS. Secara ekonomi, sempitnya lahan ekonomi masyarakat dan kondisi ekonomi yang rentan, serta keberadaan HGU di Kota Padang menjadi ironi, karena semakin menunjukan bahwa sistem pembangunan tidak berpihak pada para petani. Realitasnya, luas lahan yang dikuasai para petani sangat kecil, bahkan lebih dari 8o\% warganya hanya memiliki lahan untuk bertani sekitar o.1 hektar. Luasan lahan demikian sudah pasti tidak bisa untuk mencukupi kehidupannya, oleh karena itu harus disiasati dengan cara-cara lain. Sementara petani yang menguasai lahan 0.51 Ha kurang dari $2 \%$. Kondisi ini jelas menggambarkan situasi ekonomi masyarakat Kota Padang sangat jauh dari layak untuk hidup dengan menggantungkan sistem perekonomian berbasis tanah.

Situasi di atas diperparah dengan keberadaan konsesi HGUyang cukup besar milik PT. BMS. Tentu saja akan jauh lebih membantu masyarakat jika lahan itu diperuntukkan untuk lahan-lahan pertanian dan perkebunan warga untuk meningkatkan ekonominya. Sebagai gambaran, peta berikut menunjukkan lokasi tanah negara bekas HGU PT. BMS yang tersebar di 4 kecamatan dan 11 desa. Secara detail bisa dilihat pada gambar 1 dan tabel berikut:
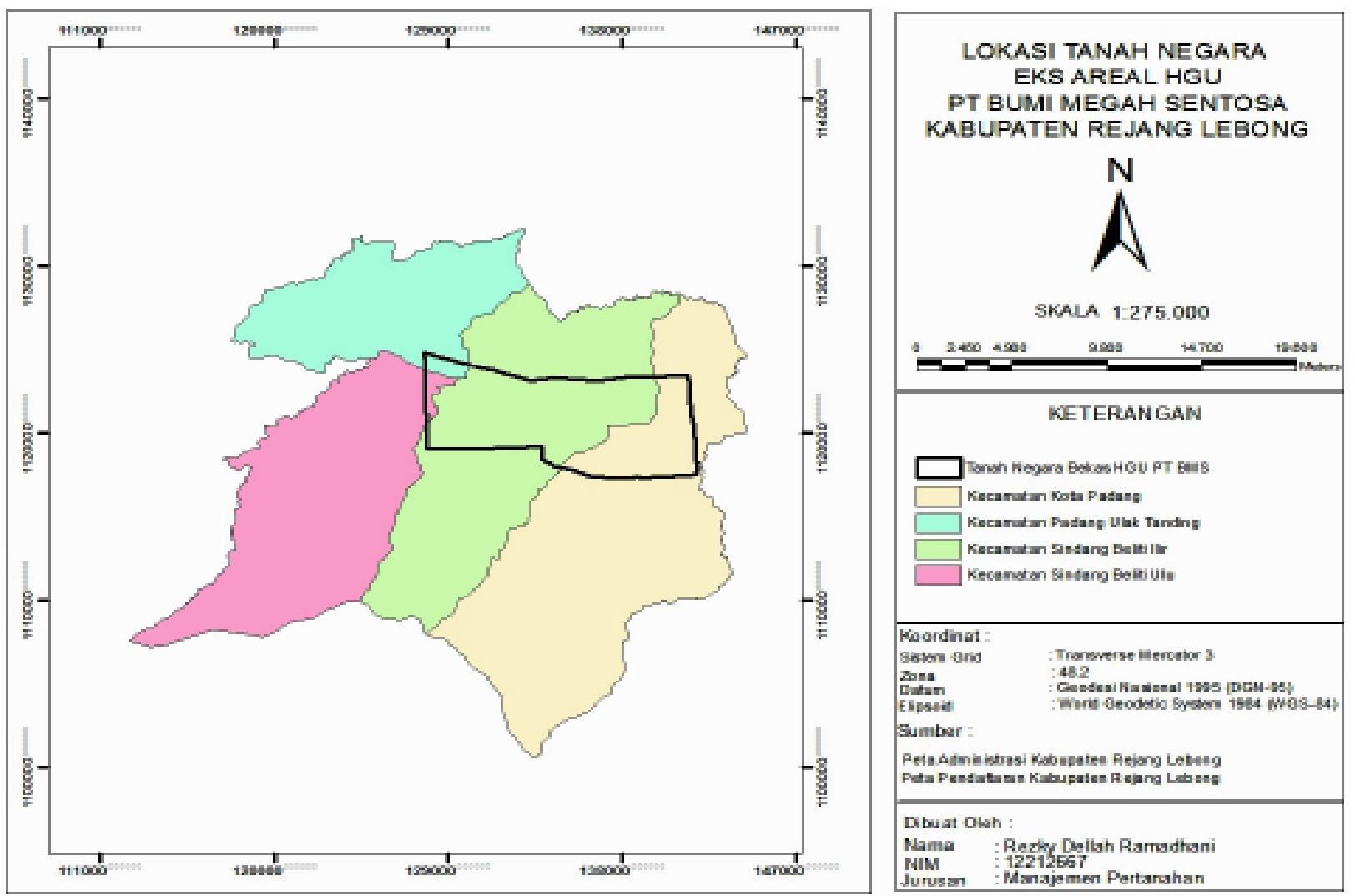

Gambar 1. Peta Lokasi Tanah Negara Bekas HGU PT. BMS. Sumber: Pengolahan data sekunder 
Tabel 2 Lokasi Tanah Negara bekas HGU PT. BMS

\begin{tabular}{|c|c|c|}
\hline No & Kecamatan & Desa/Kelurahan \\
\hline \multirow{5}{*}{1.} & \multirow{5}{*}{ Kota Padang } & Lubuk Mumpo \\
\hline & & Kota Padang \\
\hline & & Sukarami \\
\hline & & Taba Anyar \\
\hline & & Derati \\
\hline 2. & Padang Ulak Tanding & Karang Baru \\
\hline \multirow{3}{*}{3.} & \multirow{3}{*}{ Sindang Beliti Ilir } & Merantau \\
\hline & & Lubuk Belimbing I \\
\hline & & Suka Merindu \\
\hline 4. & Sindang Beliti Ulu & Tanjung Heran \\
\hline
\end{tabular}

Sumber: Kantor Pertanahan Kabupaten Rejang Lebong 2016.

Pada Gambar 1 terlihat dengan jelas, HGU yang berdiri di atas tanah warga di Kabupaten Rejang Lebong melintasi empat kecamatan, dan terbanyak wilayah desa tekena adalah Kecamatan Kota Padang. Sedikitnya lahan-lahan HGU masuk di lima desa Kec. Kota Padang yang semakin menguras lahan-lahan pertanian dan perkebunan skala kecil milik warga. Hal itu terjadi karena HGU milik PT. BMS bukan berasal dari tanah negara, melainkan tanahyang "dikuasai" masyarakat yang dibebaskan. Ironinya, lahan tersebut setelah dikeluarkan haknya justru ditelantarkan pemiliknya.

\section{HGU PT. BMS: Perolehan Haknya yang Cacat}

Program pembangunan lima tahun (Pelita I dan II) tahun 1969-1974, dan tahun 1974-1979 mencanangkan peningkatan sektor pertanian terutama beras untuk memenuhi kebutuhan pangan, hal yang sama juga dicanangkan di Provinsi Bengkulu, sebagaimana sesuai dengan program Pelita I dan Pelita II (Pemda Bengkulu tt, 6o). Pada Pelita III (1979-1984), Pemerintah Provinsi Bengkulu, membuat kebijakan di bidang perkebunan untuk mendorong perkembangan daerah Bengkulu dan meningkatkan pertumbuhan ekonomi dengan membuka peluang bagi para investor untuk menanamkan modal di bidang perkebunan. Oleh karena itu, dalam rangka menunjang program tersebut, maka dilakukan pencadangan tanah seluas 400.000 Ha untuk perkebunan besar, baik dengan pola Perkebunan Inti Rakyat (PIR) maupun Perkebunan
Besar Swasta (PBS), berdasarkan Surat Keputusan Gubernur Kepala Daerah Tingkat I Bengkulu No. 241 Tahun 1983 (Komunikasi dengan Supriyadi BR 2016).

Program pencadangan tanah perkebunan tersebut mampu menarik penanam modal dari beberapa perusahaan perkebunan, dari lahan 400.0oo Ha yang dicadangkan sampai pertengahan tahun 1988 sudah tersalurkan untuk perkebunan \pm 245.ooo Ha kepada 73 perusahaan terutama untuk tanaman karet, kelapa sawit, dan coklat (Komunikasi dengan Maulitha, 2016). Salah satu perusahaan yang menanamkan modalnya adalah PT. BMS (Komunikasi dengan Supriyadi BR 2016). PT BMS merupakan perusahaan swastayang didirikan pada tanggal 9 September 1986 dengan Akta Pendirian Nomor 24 yang dibuat di hadapan Drs. H. Saidus Sjahar S.H, Notaris di Jakarta dan telah beberapa kali diubah, terakhir diubah dengan Akta Nomor 86 tanggal 24 April 1987, sebagaimana dimuat dan telah diumumkan dalam Berita Acara Republik Indonesia tanggal 18 Agustus 1987 Nomor 66 dengan tambahan Nomor 769 .

Pada tanggal 12 November 1986, melalui surat No. HK. 350/Ec.220, Menteri Pertanian Cq. Direktur Jenderal Perkebunan memberikan persetujuan prinsip pengembangan tanaman coklat seluas 7.000 Ha di daerah Kecamatan Padang Ulak Tanding Kabupaten Rejang Lebong, Provinsi Bengkulu. Pemberian persetujuan prinsip pengembangan tanaman coklat kepada PT. BMS didasarkan pada surat permohonan nomor Bumi S.1186 yang diajukan PT. BMS pada tanggal 6 November 1986. Pada tanggal 17 November 1986, berdasarkan kajian dari Tim Pertimbangan Lahan untuk pengembangan usaha peningkatan produksi daerah Provinsi Bengkulu, maka Gubernur Provinsi Bengkulu memberikan Persetujuan Prinsip pencadangan lahan seluas 7.0oo Ha untuk perkebunan coklat atas nama PT. BMS (Lampiran SK Gubernur Bengkulu No. 16o/IL/II/BKPMD/1987).

Menindaklanjuti persetujuan prinsip tersebut, 
pada tanggal 6 Februari 1987, melalui surat Nomor. Bumi. 13, PT. BMS mengajukan permohonan Izin Lokasi dan Pembebasan Hak/Pembelian Tanah seluas 7.ooo Ha untuk lahan perkebunan coklat di Kecamatan Kota Padang Kabupaten Rejang Lebong. Permohonan tersebut dikabulkan oleh Gubernur Provinsi Bengkulu pada tanggal 14 Maret 1987 melalui SK Gubernur Bengkulu No. 16o/IL/II/ BKPMD/1987 tentang Izin Lokasi dan Pembebasan Hak/Pembelian Tanah seluas 7.ooo Ha untuk lahan perkebunan coklat di Kecamatan Kota Padang Kabupaten Rejang Lebong.

Setelah mendapatkan izin lokasi, maka investor sudah dapat melakukan kegiatan perolehan tanah, jika kegiatan perolehan tanahanya sudah selesai, maka investor baru dapat mengajukan permohonan hak atas tanah. Sebagaimana yang disebutkan pada Pasal 2 Surat Keputusan Gubernur Kepala Daerah Tk. I Bengkulu No. 16o/IL/II/ BKPMD/1987 Persetujuan tanggal 14 Maret 1987 tentang Izin Lokasi dan Pembebasan Hak/Pembelian Tanah seluas 7.0oo Ha untuk lahan perkebunan coklat di Kecamatan Kota Padang:

PT. Bumi Mega Sentosa selambat-lambatnya 6 (enam) bulan sejak tanggal Surat Keputusan ini harus sudah menyelesaikan Pembebasan Hak/Pembelian Tanah serta kegiatan-kegiatan lainnya pada areal tersebut sesuai dengan ketentuan yang berlaku.

Kenyataannya setelah mendapatkan izin lokasi, PT. BMS belum melakukan pembebasan tanah masyarakat melainkan terlebih dahulu mengajukan permohonan hak atas tanah (Komunikasi dengan Zulkarnain 2016). PT. BMS mengajukan permohonan HGU dengan surat pengantar dari Ketua Badan Koordinasi Penanaman Modal Jakarta pada tanggal 21 Juli 1987 No. 433/A.4/1987. Atas permohonan tersebut, Panitia Pemeriksaan Tanah B Provinsi Bengkulu dalam Risalahnya tanggal 27 Juni 1897 No. 11/RSL/B/1987, menyatakan permohonan tersebut dapat diluluskan untuk diberikan HGU seluas $\pm 7.000 \mathrm{Ha}$, dengan alasan karena lokasi tersebut telah diperuntukkan untuk perkebunan besar di Provinsi Bengkulu. Tanah yang dimohonkan HGU PT. BMS setelah dilakukan pengukuran secara kadastral, diperoleh hasil pengukuran keliling seluas 6.925 Ha yang dimuat dalam Peta Situasi tanggal ${ }_{31}$ Agustus 1987 No. 20/1987.

Tim Pertimbangan HGU Perkebunan Besar di Jakarta telah memberikan pertimbangan kepada Menteri Dalam Negeri agar permohonan tersebut dapat disetujui untuk dikabulkan, dengan diberikan HGU selama 30 tahun atas tanah seluas 6.925 Ha telah dianggap sesuai dengan Pasal 20 ayat (1) Peraturan Menteri Dalam Negeri No. 5 Tahun 1973 tentang Ketentuan-Ketentuan Mengenai Tata Cara Pemberian Hak Atas Tanah. Atas dasar tersebut, diterbitkanlah Surat Keputusan Menteri Dalam Negeri Nomor 03/HGU/1988 tanggal 12 Februari 1988 tentang Pemberian Hak Guna Usaha Atas Nama PT. BMS dengan peruntukan tanaman coklat (Lampiran 4). Surat Keputusan Menteri Dalam Negeri Nomor 03/HGU/1988 tanggal 12 Februari 1988 tersebut merupakan dasar penerbitan sertipikat HGU Nomor 1/RL/1988 atas nama PT. BMS yang berkedudukan di Jakarta yang terletak di Desa Merantau, Lubuk Belimbing I, Karang Baru, Tanjung Heran, Suka Merindu, Kikim, Lubuk Mumpo, Kota Padang, Sukarami, dan Taba Anyar Kecamatan Kota Padang, Kabupaten Rejang Lebong dengan Gambar Situasi Nomor 134/1988 tanggal 14 April 1988 seluas 6.925 Ha.

Menurut Zulkarnain, proses pemberian HGU PT. BMS tidak sesuai dengan mekanisme yang benar. HGU diberikan sebelum dilakukan pembebasan lahan, sehingga pada Diktum Kedua Poin c SK Pemberian HGU PT BMS, menyebutkan:

Apabila di dalam area yang diberikan dengan Hak Guna Usaha ini ternyata masih terdapat pendudukan/penggarapan rakyat secara menetap dan belum mendapat penyelesaian, maka menjadi kewajiban dan tanggung jawab sepenuhnya dari penerima hak untuk menyelesaikan dengan sebaik-baiknya menurut ketentuan peraturan yang berlaku (SK Mendagri No. 03/HGU/1988).

Pemberian HGU terkesan dipaksakan dan 
melanggar prinsip kehati-hatian, karena pada kenyataannya, tanah belum dalam status dibebaskan, artinya belum clear and clean. Kebijakan itu diambil semata hanya untuk kepentingan pemerintah daerah untuk memperbesar masuknya investor di Bengkulu. Upaya itu memang berhasil meningkatkan jumlah penanam modal di bidang perkebunan di Bengkulu dalam waktu yang relatif singkat karena ada kemudahan yang diberikan oleh pemerintah daerah (Komunikasi dengan Zulkarnain 2016).

Menilik status tanah areal HGU PT. BMS, sebagaimana yang disebutkan pada Surat Keputusan Menteri Dalam Negeri Nomor 03/HGU/1988 tanggal 12 Februari 1988 bahwasannya HGU PT. BMS berasal dari tanah negara/kawasan hutan. Kenyataannya, tanah areal HGU PT BMS yang berasal dari tanah yang dicadangkan untuk perkebunan besar, merupakan tanah yang diklaim milik masyarakat atau tanah yang sudah digarap oleh masyarakat berpuluh-puluh tahun secara turun temurun dan diperkuat oleh pernyataan dari Zulkarnaian, menyatakan:

Tanah yang akan diberikan kepada PT. BMS bukan tanah negara. Tanah tersebut adalah tanah masyarakat yang baru akan dibebaskan dengan pemberian ganti rugi, namun yang akan diganti rugi bukan tanahnya melainkan hanya tanam tumbuh yang ada di atas tanah tersebut.

Secara adat, masyarakat telah lama menguasai lahan-lahan tersebut, walaupun sebagian tidak memiliki alas hak sebagai bukti kepemilikan, sebagian lagi mengatakan bahwa alat buktiyang dimiliki masyarakat diserahkan kepada PT. BMS ketika akan dilakukan pembebasan tanah. Hal itu juga yang membuat masyarakat merasa yakin mengerjakan lahan tersebut karena apa yang telah diserahkan kepada perusahaan tidak sesuai kesepakatan, sehingga reklaiming dilakukan. Secara historis, tabel 3 memperlihatkan asal usul status tanah areal HGU PT. BMS sebagaimana dapat dilihat berikut ini:
Tabel 3 Status Tanah Areal PT BMS

\begin{tabular}{|c|l|c|}
\hline No. & \multicolumn{1}{|c|}{ Status Tanah } & $\begin{array}{c}\text { Luas } \\
\text { Perkiraan(Ha) }\end{array}$ \\
\hline 1. & Hak Milik & 1.450 \\
\hline 2. & $\begin{array}{l}\text { Hak Bersama Masyarakat Adat Suku } \\
\text { Tengah Kepungut }\end{array}$ & 1.150 \\
\hline 3. & Hak Garap/Hak Pakai $^{8}$ & 4.325 \\
\hline \multicolumn{2}{|c|}{ Jumlah $^{2}$} & 6.925 \\
\hline
\end{tabular}

Sumber: Komunikasi dengan Mantan Karyawan PT. BMS dan Mantan Kepala Seksi Pendaftaran Tanah Kabupaten Rejang Lebong Tahun 1988

Sebagaimana yang dijelaskan sebelumnya bahwa tanah yang dimohonkan oleh PT. BMS adalah tanah hak perorangan/garapan masyarakat Suku Tengah Kepungut, dengan melakukan pembebasan tanah agar menjadi tanah negara, dengan cara pemberian ganti rugi. Salah satu persoalannya adalah upaya pembebasan tanah areal HGU PT. BMS dilakukan setelah HGU diberikan oleh negara, sehingga dalam hal penentuan besarnya ganti kerugian pihak PT. BMS tidak berkoordinasi dengan pihak lain kecuali langsung berkoordinasi dengan masyarakat pemilik tanah (Komunikasi dengan Zulkarnain 2016). Hal itu juga yang tercantum dalam salah satu Diktum Kedua SK Mendagri No. 03/HGU/1988, ini sejak awal sudah bermasalah, karena membiarkan masyarakat berurusan langsung dengan korporasi, dan negara tidak hadir memberi solusi.

Pada praktiknya, PT. BMS mengalami kesulitan berkomunikasi dengan masyarakat, sehingga mengandalkan pamong desa untuk melakukannya (Komunikasi dengan mantan karyawan PT. BMS). Menurut beberapa masyarakat, bahwa dalam

${ }^{7}$ Hak bersama tersebut mengandung hak peserta bagi para anggota marga dan memberikan wewenang kepada para anggotanya untuk menikmati segala hasil dari tanah, selama seseorang menjadi anggota keluarga suatu marga, hak pesertanya tidak dapat diganggu gugat dan tidak dapat dikurangi (Siddik, 1980: 137).

${ }^{8}$ Hak pakai anggota masyarakat hukum adat atas tanah dimulai dari menebang pohon, membuka ladang sampai mengambil hasil. Apabila ladang tersebut diubah menjadi kebun dengan tanaman muda atau tua atau tanah tersebut diusahakan maka hak pakai itu berkembang menjadi hak milik (Siddik, I980: 15I). 
proses pembebasan tanah, pihak PT. BMS tidak melakukan musyawarah dengan pemilik tanah mengenai besarnya ganti rugi yang akan diberikan melainkan hanya berkoordinasi dengan beberapa tokoh masyarakat. Musyawarah tersebut membahas terkait jangka waktu HGU adalah 25 tahun dan apabila jangka waktu 25 tahun HGU tersebut berakhir maka tanah tersebut akan dikembalikan kepada pemilik semula sehingga dalam pembebasan tanah tersebut yang akan diganti rugi hanya atas tanam tumbuhnya saja, bukan tanahnya. Padahal, SK Mendagri No. 03/HGU/1988 tanggal 12 Februari 1988 memutuskan jangka waktu HGU PT. BMS adalah $z$ tahun.

Pembebasan tanah hanya dilakukan dengan ganti rugi tanam tumbuh (bukan harga tanah) senilai Rp.10.00o sampai dengan Rp.25.0oo tanpa ada kesepakatan harga dengan pemilik tanah, sehingga banyak masyarakat yang menolak pemberian ganti rugi, namun beberapa masyarakat tetap menerima ganti rugi dengan pertimbangan bahwa setelah 25 tahun tanah akan dikembalikan kepada mereka. Atas realitas tersebutlah terjadi tumpang tindih penguasaan dan kepemilikan tanah di area HGU PT. BMS, karena perusahaan tidak menjalankan sesuai ketentuan yang berlaku dan negara absen dalam hal ini. Jelas tanah belum clear and clean, sementara negara sudah menerbitkan HGU di atas tanah tersebut, artinya HGU belum selesai dan masih berkonflik, seharusnya permohonannya ditolak. Dari total luasan hakyang diberikan kepada PT. BMS, hanya sedikit yang berhasil dibebaskan. Secara rinci sebagaimana tabel berikut ini.

Tabel 4 Luas Areal yang telah Dibebaskan oleh PT. BMS

\begin{tabular}{|l|l|c|c|}
\hline No. & \multicolumn{1}{|c|}{ Status Tanah } & $\begin{array}{c}\text { Luas } \\
\text { Perkiraan } \\
\text { (Ha) }\end{array}$ & $\begin{array}{c}\text { Tanah yang } \\
\text { Sudah } \\
\text { dibebaskan (Ha) }\end{array}$ \\
\hline 1. & Hak Milik & 1.450 & 325 \\
\hline 2. & $\begin{array}{l}\text { Hak Bersama Masyarakat } \\
\text { Adat Suku Tengah Kepungut }\end{array}$ & 1.150 & 50 \\
\hline 3. & Hak Garap/ Hak Pakai & 4.325 & 1.671 \\
\hline \multicolumn{2}{|c|}{ Jumlah } & 6.925 & 2.046 \\
\hline
\end{tabular}

Sumber: Komunikasi dengan Mantan Karyawan PT. BMS dan Mantan Kepala Seksi Pendaftaran Tanah Kabupaten Rejang Lebong Tahun 1988
Terhadap tanah-tanah perkebunan (HGU) yang tidak dapat dibebaskan oleh PT. BMS seharusnya dikeluarkan dari areal HGU dengan melakukan revisi SK Mendagri No. 03/HGU/1988, dimana luas tanah yang diberikan kepada PT. BMS disesuai dengan luas tanah yang telah dibebaskan agar status tanah tersebut menjadi clean and clear, sehingga tidak terjadi tumpang tindih pemilikan dan penguasaan tanah di dalam areal HGU. Kenyataannya, tidak dilakukan sehingga areal HGU PT. BMS tetap dengan luasan 6.925 Ha. Fakta ini menarik, meskipun pembebasan tanah belum sepenuhnya dilakukan, PT. BMS tetap beraktivitas di perkebunannya. Dari tanah yang telah dibebaskan, tidak juga seluruhnya ditanami coklat sebagaimana pengajuannya. Bahkan areal yang sudah ditanami tidak mencapai 1/3 dari luas areal yang sudah dibebaskan atau sekitar 578,88 Ha. dengan rincian sebagai berikut:

Tabel 5 Luas Areal yang Dimanfaatkan oleh PT. BMS

\begin{tabular}{|l|l|c|}
\hline No & Tahun & Luas Tanah yang Ditanamai Coklat (Ha) \\
\hline 1. & 1988 & 6,30 \\
\hline 2. & 1989 & 455,18 \\
\hline 3. & 1990 & 73,06 \\
\hline 4. & 1991 & 44,34 \\
\hline \multicolumn{2}{|c|}{ Jumlah } & 578,88 \\
\hline
\end{tabular}

Sumber: Komunikasi dengan Mantan Karyawan PT. BMS dan Mantan Kepala Seksi Pendaftaran Tanah Kabupaten Rejang Lebong Tahun 1988

Menurut informasi yang penulis dapatkan di lapangan, sistem penanaman coklat hanya dilakukan di sepanjang jalan sampai ke dalam 100-150 m ke sebelah kanan dan kiri jalan. Hal tersebut dilakukan dengan beberapa alasan:

a. PT. BMS tidak mampu membebaskan seluruh kebun-kebun masyarakat.

b. PT. BMS tidak memiliki modal yang cukup meskipun kenyataannya pada tanggal o2 Mei 1988, HGU PT. BMS dibebankan dengan hipotik No. 594.4/Hip/o1/1988 tanggal 28 April 1988 sebesar Rp.14.00o.ooo.ooo di Bank BDN yang

${ }_{9}^{9}$ Bank Dagang Negara adalah sebuah bank pemerintah yang pernah ada di Indonesia dan merupakan 
berkedudukan di Jakarta (Salinan Buku Tanah HGU No. 1/RL/1988).

c. Sistem penanaman yang dilakukan PT. BMS merupakan strategi untuk mengelabuhi pemerintah apabila melakukan pengecekan atas kebun (Komunikasi dengan mantan karyawan PT. BMS, 2016).

PT. BMS mulai menaman coklat pada tahun 1988 sampai dengan tahun 1991, pada tanah seluas \pm 578,88 Ha. Sedangkan luasan lainnya tetap digarap oleh masyarakat, karena belum ada ganti rugi di atas lahan mereka. Selain menanam coklat, PT. BMS juga memungut hasil hutan berupa kayu meranti yang memang sudah ada sejak awal (Komunikasi dengan mantan karyawan PT. BMS 2016). Selama melakukanaktivitas perkebunana, PT. BMS baru berproduksi 1 kali panen, yaitu pada tahun 1992 menghasilkan sekitar 90 ton coklat, dengan harga Rp. 1.000.00o per ton.

\section{Masyarakat Melawan: Diambilalih Kembali}

Obyek penelitian ini secara yuridis merupakan tanah yang dikuasai langsung oleh negara, namun kenyataan di lapangan, tanah secara fisik dikuasai oleh masyarakat. Masyarakat yang menggarap tanah tersebut merupakan pemilik awal, beberapa bagian dari meraka adalah anak keturunan dan generasi penerus orang tuanya/keluarganya.

Faktor ekonomi dan keterbatasan pemilikan tanah pertanian merupakan salah satu alasan masyarakat melakukan penggarapan atas tanah HGU PT. BMS, seperti yang dikemukakan oleh sebagian warga yang menggarap areal di perkebunan tersebut bahwa:

Mata pencaharian pokok kami adalah petani tetapi kami sudah tidak mempunyai tanah untuk digarap sehingga kami tidak bisa memenuhi kehidupan sehari-hari, makanya kami menggarap tanah milik PT. BMS.

salah satu bank tertua di Indonesia. Bank ini di merger dengan tiga bank lainnya pada Juli 1999 untuk membentuk Bank Mandiri.
Sudah pasti warga yang menggarap tanah dengan alasan tanah mereka tidak pernah dibebaskan ataupun diberi ganti rugi oleh pihak manapun, termasuk PT. BMS. Masyarakat menganggap bahwa mereka masih merupakan pemilik tanah sehingga terdapat tumpang tindih pemilikan dan penguasaan tanah pada areal HGU PT BMS. Salah satu tumpang tindih pemilikan dan penguasaan tanah tersebut dapat dilihat pada gambar berikut ini:

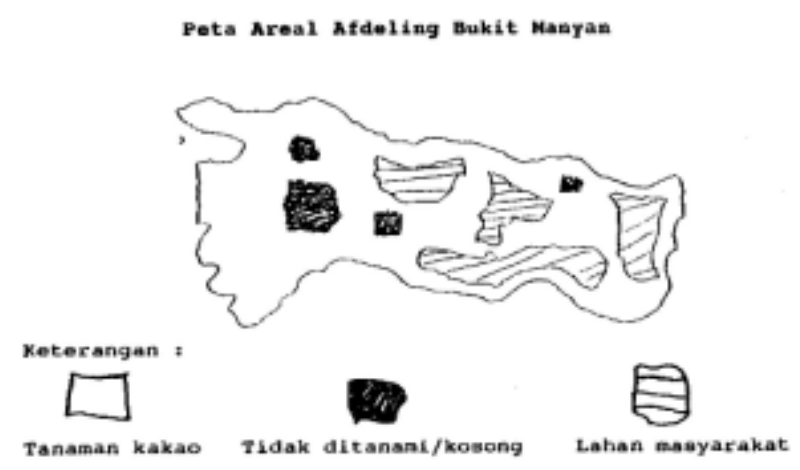

Gambar 2. Peta Areal Afdeling Bukit Manyan

Sebagian para penggarap juga berdalih, mereka adalah pemilik awal tanah yang telah diberi ganti rugi, tetapi karena sejak tahun 1997 PT. BMS menelantarkan tanah menjadi semak belukar, maka tanah kembali digarap oleh bekas pemilik awal sebagaimana pernah dijanjikan oleh PT. BMS hanya akan digunakan selama 25 tahun. Menurut beberapa sumber di lapangan, PT BMS meninggalkan tanah tersebut karena mengalami kebangkrutan.

Keberadaan PT. BMS menyebabkan masyarakat yang terkena pembebasan tanah areal HGU PT BMS kehilangan pekerjaan pokok mereka karena berkurangnya luas areal pertanian yang merupakan sumber mata pencaharian untuk menunjang kehidupan mereka. Keadaan ini menjadikan masyarakat beralih profesi menjadi buruh harian lepas di perkebunan coklat PT. BMS, namun PT. BMS tidak mampu menampung seluruh tenaga kerja yang merupakan masyarakat terkena dampak pembebabasan tanah. Selain itu, mereka juga sulit untuk mencari pekerjaan di luar Kecamatan Kota 
Padang karena tingkat pendidikannya relatif rendah sehingga banyak masyarakat yang menjadi pengangguran.

Masyarakat yang telah diberi ganti rugi mayoritas bekerja sebagai buruh harian lepas, namun tidak bertahan lama karena mereka tidak terbiasa bekerja secara beraturan dan di bawah perintah. Permasalahan tenaga kerja menyebabkan PT. BMS mengalami kerugian menyebabkan pada awal tahun 1991, PT BMS melakukan pemutusan hubungan kerja terhadap beberapa buruh. Selanjutnya pada bulan-bulan berikutnya banyak juga buruh yang mengundurkan diri karena gaji yang kecil dan pembayarannya tidak tepat waktu. Beberapa hal tersebut di atas menyebabkan PT. BMS perlahan-lahan bangkrut hingga pada tahun 1994 PT. BMS meninggalkan perkebunan tersebut.

Di sisi lain, menurut salah satu informan kebangkrutan tersebut disebabkan karena PT. BMS tidak fokus dalam memanfaatkan perkebunan coklat di Kabupaten Rejang Lebong, karena PT. BMS melakukan usaha perkebunan lainnya di daerah Jambi sejak tahun 1991 (Komunikasi dengan mantan karyawan PT.BMS 2016). Tanah seluas 2.046 Ha yang telah ditinggalkan oleh PT. BMS tidak secara langsung digarap oleh masyarakat. Penggarapan lahan kembali dimulai tahun 1997. Sejak tahun itu hingga sekarang, perkebunan yang dikelola masyarakat tersebut merupakan perkebunan yang produktif yang hasilnya dapat digunakan untuk memenuhi kebutuhan hidup mereka sehari-hari.

Atas situasi reklaiming tersebut pemerintah daerah sementara merespon dengan cukup arif, namun sampai saat ini belum membuat keputusan apapun terkait status tanah sebagaimana tuntutan warga. Dalam sebuah wawancara dengan penulis, Bupati Rejang Lebong menyampaikan:

Penggarapan tanah yang dilakukan oleh masyarakat atas tanah tersebut tidak perlu dipermasalahkan apabila masyarakat hanya memanfaatkan agar tanah tersebut tetap produktif sehingga tidak terlantar. Namun hal tersebut bisa menjadi masalah apabila masyarakat menuntut untuk diberikan hak (Komunikasi dengan Hijazi, Bupati Rejang Lebong 2016).

Statemen bupati cukup membuat cemas warga, karena faktanya, sejak penggarapan tanah dimulai tahun 1997 hingga saat ini, tidak sedikit masyarakat yang mengupayakan menuntut untuk dapat diberikan haknya terhadap tanah yang mereka garap, karena sejak awal tanah mereka tidak pernah dibebaskan. Masyarakat merasa apa yang dilakukan sudah benar, mengambil haknya yang selama ini tidak diberikan. Namun sejauh ini masih jauh dari harapan, dan statemen Bupati Rejang Lebong justru dianggap semakin menjauhkan harapan masyarakat.

\section{E. Pembatalan HGU PT. Bumi Megah Sentosa}

Pada tahun 1997/1998, Dinas Perkebunan Provinsi Bengkulu melakukan klasifikasi terhadap 41 perkebunan besaryang ada di Provinsi Bengkulu. Aspek-aspek yang dinilai dalam klasifikasi kebun yaitu aspek manajemen, aspek fisik kebun, pengolahan/pemasaran dan lingkungan. Berdasarkan hasil klasifikasi tersebut terdapat 4 kategori kelas kebun, yaitu kelas II, III, IV, dan kelas V (Komunikasi dengan Maulitha 2016). Secara rinci disampaikan oleh Dinas Perkebunan Provinsi Bengkulu sebagai berikut:

Tabel 6 Hasil Klasifikasi Kelas Kebun Di Provinsi Bengkulu Tahun 1997/1998.

\begin{tabular}{|l|l|c|c|c|}
\hline No. & $\begin{array}{c}\text { Kelas } \\
\text { Kebun }\end{array}$ & $\begin{array}{c}\text { Jumlah } \\
\text { Perusahaan }\end{array}$ & $\begin{array}{c}\text { Luas } \\
\mathbf{( H a )}\end{array}$ & Keterangan \\
\hline 1. & Kelas II & 9 & 49.882 & Baik \\
\hline 2. & Kelas III & 10 & $\mathbf{2 3 . 6 2 3}$ & Cukup \\
\hline 3. & Kelas IV & 9 & $\mathbf{2 2 . 4 8 9}$ & Kurang \\
\hline 4. & Kelas V & 13 & $\mathbf{2 7 . 5 9 5}$ & Kurang Sekali \\
\hline \multicolumn{2}{|l|}{ Jumlah } & 41 & 123.589 & \\
\hline
\end{tabular}

Sumber: Dinas Perkebunan Provinsi Bengkulu

Kebun-kebun kelas IV dan V seluas 50.084 Ha termasuk kelas kebun terlantar. Terhadap kebun kelas IV dan V, Kepala Dinas Perkebunan mela- 
kukan peringatan secara tertulis 2 sampai 3 kali dengan jeda waktu 6 bulan. Apabila 6 bulan sejak teguran kedua tidak juga berupaya melakukan perbaikan usaha perkebunannya, maka Kepala Dinas Perkebunan segera melaporkan kepada Direktur Jenderal Bina Produksi Perkebunan. Selanjutnya, atas nama Menteri Pertanian mengusulkan kepada Kepala Badan Pertanahan Nasional (BPN) untuk mencabut HGU-nya. Total ada 6 perusahaan kelas V seluas 10.982 Ha telah diusulkan untuk dicabut/dibatalkan HGU-nya, salah satunya adalah HGU yang dimiliki oleh PT. BMS, sedangkan 16 kebun kelas IV dan V lainnya seluas 39.102 Ha masih dalam tahap pembinaan (Komunikasi dengan Maulitha 2016).

Menurut Rosy Maulitha, ada beberapa kriteria yang menyebabkan perkebunan milik PT. BMS termasuk dalam klasifikasi kebun kelas V, di antaranya adalah:

1. PT. BMS tidak menyampaikan laporan kegiatan atau kinerja dalam pengelolaan perkebunan coklat.

2. Pada pemeriksaan lapangan didapatkan bahwa tidak ada aktivitas perkebunan yang dilakukan oleh PT. BMS sehingga tidak berproduksi.

3. Tanah perkebunan tersebut sudah dikuasai masyarakat hampir 90\%.

Berdasarkan usulan dari Dinas Perkebunan Provinsi Bengkulu, Gubernur mengusulkan pembatalan hak atas tanah perkebunan PT. BMS berdasarkan Surat Nomor 167/1999/I/B.1 tanggal 24 November 1999. Selanjutnya Direktur Jenderal Perkebunan, Departemen Kehutanan dan Perkebunan pada tanggal 18 Februari 2000 dengan Nomor 88/VII-PKU/200o juga mengusulkan pembatalan hak atas pemberian HGU dan pencabutan tanah perkebunan PT. BMS kepada Kepala Badan Pertanahan Nasional (Kep. Ka BPN No. 11-VIII200o). Hal yang sama juga dilakukan oleh Kepala Kanwil BPN Bengkulu melalui surat No. 500-081 tanggal 31 Januari 2000 yang mengusulkan kepada Kepala BPN RI untuk membatalkan 7 (tujuh) HGU terlantar di Provinsi Bengkulu, salah satunya adalah HGU PT. BMS. Sudah jelas disebutkan di atas, bahwa usulan pembatalan HGU PT. BMS diawali dari hasil kajian Dinas Perkebunan Bengkulu yang memberikan penilaian kinerjanya pada level V, artinya sangat buruk, sehingga layak untuk dicabut status HGU-nya, sebagaimana juga dijelaskan oleh Zulkarnain dan Pungadi.

Akhirnya, pada tahun 200o, SK pembatalan HGU PT. BMS dikeluarkan oleh Ka. BPN dengan pertimbangan pokok atas rekomendasi dari kajian Dinas Perkebunan Bengkulu (SK Ka. BPN No. 11VIII/200o). HGU milik PT. BMS otomatis hapus dan tanah langsung dikuasai oleh negara atau sering disebut kembali menjadi tanah negara. Persoalannya, bagaimana status hukum atas tanah tersebut yang dahulu perolehannya tidak sesuai prosedur, pembebasan lahan masyarakat tidak melalui proses ganti rugi yang benar, sementara kini status hak tanah tersebut "milik" atau dikuasai oleh negara. Ini yang menjadi sumber persoalan, negara telah melakukan "negaraisasi tanah masyarakat". Mestinyayang menjadi tanah negara hanya yang dibebaskan oleh PT. BMS yakni seluas 2.046 Ha dari total $6.925 \mathrm{Ha}$, bukan keseluruhan tanah warga. Akan tetapi memang problematis karena negara (BPN) melakukan kekeliruan yang cukup serius dengan tidak melakukan revisi atas HGUyang diterbitkan, padahal jelas PT. BMS hanya berhasil membebaskan kurang dari 1/3 hak yang diberikan.

Muncul beberapa perdebatan terkait pembatalan HGU oleh Badan Pertanahan Nasional yang dianggap hanya memiliki kewenangan membatalkan HGU-nya, namun tidak bisa membatalkan hak kepunyaan (hak keperdataan), karena ini dianggap ranah pengadilan perdata. Beberapa pihak menilai dengan merujuk pendapat Budi Harsono (2008), bahwa mereka tidak mengakui adanya hak kepunyaan bagi bekas pemegang HGU PT. BMS. Pemegang hak tidak lagi memiliki kewenangan atas tanah yang telah dibatalkan haknya atau dengan kata lain hak kepunyaannya hapus 
karena bekas pemegang hak tidak memenuhi kewajibannya dalam memanfaatkan tanah tersebut sesuai dengan peruntukannya (Komunikasi dengan Zulkarnain \& Pungadi 2016). Secara legal formal memang sedikit problematis terkait hak keperdataan di atasnya, penulis melihat ada peluang perdebatan lebih lanjut terkait hak keperdataan PT. BMS, namun seharusnya hanya seluas tanah yang telah dibebaskan, yaitu 2.046 Ha, sampai ada pelepasan hak kepunyaan dari bekas pemegang hak. Sejauh tidak pelepasan, maka masih terdapat peluang gugat menggugat di ranah pengadilan dan terkait sisa tanah yang tidak pernah dibebaskan yaitu 4.879 Ha seharusnya kembali secara otomatis kepada masyarakat yang memiliki dan menguasai tanah tersebut.

Mengenai hak-hak yang sudah terdaftar, dalam rangka pemeliharaan data pendaftaran tanah maka hapusnya hak atas tanah dicatat dalam buku tanah dan sertipikatnya, kemudian buku tanah dan sertipikat tersebut dimatikan. Ketentuan ini diatur dalam Pasal 52 ayat (1) PP No. 24 Tahun 1997 tentang Pendaftaran Tanah, lebih rinci terdapat dalam Pasal 131 PMNA/KBPN No. 3 Tahun 1997 tentang Ketentuan Pelaksanaan Peraturan Pemerintah Nomor 24 Tahun 1997 tentang Pendaftaran Tanah. Apabila sertipikat yang dihapus tidak diserahkan ke kantor pertanahan, maka hal tersebut dicatat pada buku tanah dan surat ukur yang bersangkutan, dalam hal ini Kepala Kantor Pertanahan dapat mengumumkan hapusnya hak yang sertipikatnya tidak diserahkan kepadanya untuk mencegah dilakukannya perbuatan hukum mengenai tanah yang sudah tidak ada haknya tersebut.

Faktanya, pembatalan HGU PT. BMS yang menyebabkan hapusnya hak atas tanahnya tidak dicatat dalam buku tanah dan sertipikatnya karena sertipikat tidak diserahkan ke Kantor Pertanahan, sementara di sisi lain, data menunjukkan sertipikat HGU PT. BMS telah dibebankan dengan hipotik No. 594.4/Hip/o1/1988 tanggal 28 April 1988 sebesar Rp.14.ooo.ooo.ooo di Bank Dagang Negara.
Sempat ada kekhawatiran, lahan tersebut masuk dalam agenda lelang BDN, namun setelah dilakukan pengecekan, lahan dengan Sertipikat HGU PT. BMS tidak tersedia dan tidak termasuk dalam asset yang akan di lelang. Persoalan belum selesai karena BDN menyarankan agar dicek ke Bank Mandiri sebagai pihak yang mengakuisi BDN, barangkali catatan terhutang ada di Bank Mandiri. Sejauh ini Bank mandiri tidak pernah memberi konfirmasi resmi walau surat klarifikasi sudah diajukan (Komunikasi dengan Supriyadi BR 2016).

Secara administrasi, seharusnya lewat SK Kepala BPN No. 11-VIII-20oo tentang Pembatalan HGU cukup untuk dijadikan dasar dalam pencatatan hapusnya HGU PT. BMS pada Buku Tanah dan Daftar Umum lainnya, meskipun sertipikat HGU Nomor 1/RL/1988 tidak diserahkan ke kantor pertanahan. Hal ini diperkuat dengan pendapat Maria Sumardjono (2010), bahwa terjadi pembatalan hak maka hak atas tanah yang dibebani HT hapus dan tanahnya menjadi tanah negara. Akibatnya, HT juga hapus dengan hapusnya hak atas tanah, namun demikian hutang tidak menjadi hapus sebelum dilunasi. Jika hal tersebut terjadi, kedudukan pemegang HT berubah dari kreditur preferent $^{10}$ menjadi kreditur konkuren. ${ }^{11}$ Oleh karena itu untuk mengantisipasi hal tersebut maka pada Akta Pemberian Hak Tanggungan dapat dicantumkan janji bahwa pemberi HT akan mengganti obyek HT apabila obyek tersebut dibatalkan haknya.

ro Kreditur preferen adalah kreditur yang mempunyai hak pengambilan pelunasan terlebih dahulu daripada kreditur lain dan kreditur preferen itu tagihannya didahulukan atau di istimewakan daripada tagihantagihan kreditu lain.

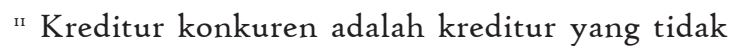
mempunyai hak pengambilan pelunasan terlebih dahulu daripada kreditur lain dan kreditur konkuren itu piutangnya tidak dijamin dengan suatu hak kebendaan tertentu. 


\section{F. Penguatan Hak: Solusi Bagi Petani Penggarap dan Alternatif Kebijakan}

Masyarakat menguasai tanah negara sejak tanah tersebut masih dilekati HGU PT. BMS hingga saat ini ketika tanah tersebut sudah berstatus tanah negara. Sebagian masyarakat yang mengklaim bahwa tanah tersebut masih milik mereka karena tidak pernas dibebaskan oleh PT. BMS mengharapkan adanya kepastian akan tanah tersebut.

Beberapa dari masyarakat tersebut pernah berupaya mengajukan permohonan hak milik kepada Kantor Pertanahan Kabupaten Rejang Lebong namun hal tersebut ditolak. Penolakan tersebut didasarkan pada adanya SK Gubernur Nomor 286/2002 tanggal 6 Juni 2002 tentang Pengaturan Penguasaan dan Penggunaan Tanah Terhadap Tanah Bekas Hak Guna Usaha Terletak di Kabupaten Rejang Lebong Provinsi Bengkulu, yang pada Diktum Ketiga menyatakan bahwa:

Pengaturan penguasaan dan penggunaan tanah dimaksud dalam diktum pertama dan kedua keputusan ini pelaksanaannya diserahkan kepada Bupati Rejang Lebong.

Kewenangan penuh izin Bupati Kabupaten Rejang Lebong yang diberikan mandat oleh gubernur. Atas realitas tersebut, Kantor Pertanahan Kabupaten Rejang Lebong berupaya melakukan penguatan hak secara menyeluruh bagi petani penggarap tanah negara di Kecamatan Kota Padang. Penguatan hak ini diupayakan karena sebagian besar lahan di atas HGU PT. BMS berasal dari tanah masyarakat tidak pernah dibebaskan, sehingga dapat diprioritaskan untuk memperoleh hak atas tanah. Upaya Kantor Pertanahan Rejang Lebong sudah coba dilakukan dengan membangun skema menjadikan objek tersebut sebagai Tanah Obyek Landreform (TOL), yang kemudian akan diredistribusikan dan diberikan Hak Milik kepada masyarakat khususnya petani penggarap. Selain tuntutan masyarakat, tujuan lain jelas persoalan upaya meningkatkan kesejahteraan petani penggarap dan memberikan kepastian hukum atas tanah yang mereka garap tersebut yang merujuk pada PP 224/1961 (Komunikasi dengan Supriyadi BR 2016).

Kebijakan dengan skema redistribusi tanah dapat diterapkan dalam rangka memberikan perlindungan hukum terhadap masyarakat yang menguasai secara fisik tanah negara yang tidak dikelola oleh negara, redistribusi tanah ini diberikan kepada petani penggarapyang telah menguasai tanah tersebut. Petani penggarap dianggap wajar memperoleh tanah tersebut, karena mereka telah mempunyai hubungan fisik sebelumnya dan hubungan ekonomi. Mereka telah memberdayakan sumber daya tanah sehingga memberikan manfaat yang optimal (Komunikasi dengan Anindito Kasubsi Landreform \& KT 2016). Hal ini sejalan dengan pendapat beberapa pakar, bahwasannya lahirnya hak kepunyaan selain karena penguasaan yang lama juga karena adanya hubungan ekonomi/investasi biaya dan tenaga serta adanya itikad baik (komunikasi dengan Julius Sembiring 2016).

Terkait gagasan tersebut, Kantor Pertanahan Rejang Lebong sudah melakukan upaya-upaya untuk penguatan hak masyarakat, dan bahkan sudah melakukan survey sekaligus menentukan obyeknya lewat skema redistribusi TOL di beberapa desa yang sudah disepakati, di antaranya Desa Taba Anyar, Sukarami, dan Lubuk Mumpo Kecamatan Kota Padang. Bahkan Kantah Rejang Lebong telah jauh melakukan persiapan dengan secara legal formal akhirnya terbit objek TOL lewat SK Ka. Kanwil BPN Bengkulu No. 25/Kep-17.14/I/ 2016 Tanggal 28 Januari 2016 tentang Penetapan Lokasi Kegiatan Redistribusi TOL untuk 4 desa, yaitu: Kelurahan Kota Padang, Desa Taba Anyar, Sukarami, dan Lubuk Mumpo. Namun semua upaya itu tidak dilanjutkan karena wewenang kekuasaan yang diberikan oleh gubernur kepada Bupati Rejang Lebong untuk penggunaan tanah bekas HGU ada di bupati, dan Bupati Rejang Lebong dalam komunikasi singkat kepada Kepala 
Kantah Rejang Lebong serta wawancara dengan penulis, belum memberikan restu atau izin, sehingga langkah-langkah tersebut sementara dihentikan.

Kasus ini sebenarnya menjadi pelajaran penting bagi para pengambil kebijakan dalam memberikan hak kepada pihak lain. Seharusnya, pemberian HGU tidak boleh bertentangan dengan UUPA sebagai landasan filosofisnya, karena baik proses maupun asasnya tidak dijalankan dengan tepat. Faktanya pemberian HGU PT. BMS menimbulkan persoalan akibat cacat hukum sejak awal penerbitannya. Prinsip claer and clean agar di belakang hari tidak menjadi persoalan telah diabaikan, dan kewenangan penyelesaian persoalan diberikan kepada pihak korporasi jika muncul sengketa kemudian hari dan ini seolah-olah negara melepaskan warganya langsung vis a vis dengan korporasi. Akibatnya petani dirugikan dan negara bukan memihak kapada mereka, justru melakukan negaraisasi tanah warganya.

Akibat proses yang keliru dan bermasalah, warga petani lepas dari cengkraman "korporasi" masuk ke cengkraman "negara”. Hal ini bisa dilihat dengan jelas bagaimana sikap Bupati Rejang Lebong atas tanah tersebut. Menurutnya, "Tanah tersebut merupakan aset pemerintah daerah sehingga bupati berhak menentukan kebijakan apa yang tepat dalam pengelolaan tanah negara bekas HGU tersebut, dengan pertimbangan kebijakan tersebut menguntungkan banyak pihak, baik pemerintah daerah maupun masyarakat, khususnya petani penggarap tanah tersebut" (Komunikasi dengan Bupati Rejang Lebong 2016). Selanjutnya statemen bupati menyampaikan:

Tidak dimungkinkan apabila keseluruhan tanah bekas HGU PT. BMS tersebut diberikan kepada masyarakat melalui redistribusi karena hal tersebut dapat menyebabkan pemerintah daerah kehilangan tanahnya.

Padahal di dalam aturan tegas dinyatakan, tanah negara bekas HGU PT. BMS tidak dapat serta merta menjadi aset pemerintah daerah Kabupaten Rejang Lebong. Ada beberapa syarat agar tanah dapat menjadi asset pemerintah daerah, di antaranya adalah (1) harus ada pelepasan hak kepunyaan; (2) pembelian tanah tersebut harus menggunakan biaya yang berasal dari APBD; (3) tanah tersebut harus didaftarkan sebagai asset dan (4) tanah tersebut harus disertipikatkan. Realitas ini terjadi, dimana perbedaan persepsi antara bupati dengan Kantah Rejang Lebong di dalam melihat persoalan tanah bekas HGU PT. BMS. Dan ujungnya, perbedaan itu mengorbankan kepentingan warga itu sendiri.

Seharusnya secara jernih, Bupati dan Kantah Rejang Lebong lebih mudah menyelesaikan persoalan yang sudah berlangsung cukup lama, setidaknya untuk menjamin kepastian para petani penggarapyang sudah menduduki dan menguasai cukup lama bisa diambil kebijakan redistribusi tanah untuk meningkatkan kesejahteraan dan kepastian securitas tanahnya. Jika pun tidak dilakukan redistribusi lahan, ada beberapa alternatif kebijakaan lainnya dalam rangka penguatan hak atas tanah bagi petani penggarap, misalnya: 1) Petani penggarap diberikan “Surat Izin Menggarap (SIM)”. Izin Menggarap dapat diberikan kepada petani penggarap atas "klaim" tanah negara setelah ditetapkan sebagai TOL. SIM diberikan kepada penerima redistribusi sebagaimana ditentukan pada Pasal 4 KMDN No. 38 Tahun 1981 tentang Pelaksanaan Keputusan Presiden No. 55 Tahun 1980 mengenai Perincian Tugas dan Tata Kerja Pelaksanaan Landreform. 2) "Perkebunan Inti Plasma”. Pola ini memungkinkan akan tetapi ada kekhawatiran bagi petani karena akan kembali menjadi korban dan ini walau memungkin tetapi jauh dari harapan yang seharusnya dilakukan oleh negara. Setidaknya tiga skema itu yang paling memungkinkan dalah penguatan hak dengan sistem redistribusi tanah langsung kepada petani penggarap. SIM memungkinkan akan tetapi rentan dengan kembali pengambilalihan oleh negara jika sewaktu-waktu negara membutuhkan, sehingga petani rentan untuk kembali kalah. Sementara Inti Plasma akan banyak 
memberikan kekhawatiran dan permasalahan di kemudian hari.

\section{G. Kesimpulan}

Penggarapan kembali tanah negara bekas HGU PT. BMS oleh petani penggarap disebabkan karena PT. BMS telah melakukan pencederaan kesepakatan dan proses yang benar sesuai peraturan dan kesepakatan. PT. BMS hanya membebaskan tanah seluas 2.046 Ha dari luas keseluruhan HGU yang diberikan 6.925 Ha, sehingga menyebabkan adanya tumpang tindih pemilikan dan penguasaan tanah pada areal HGU. Selain itu, penegasan hukum terhadap obyek HGU PT. BMS sebagai tanah negara menjadikan proses pemberian HGU PT. BMS menjadi cacat hukum, karena pemberian HGU dilakukan ketika PT BMS belum membebaskan tanah masyarakat.

Solusi kebijakan yang seharusnya dalam bentuk "penguatan hak melalui redistribusi tanah meskipun hapusnya hak atas tanah akibat pembatalan HGU PT. BMS belum dicatatkan pada buku tanahnya. Hal tersebut menyebabkan informasi yang ada pada buku tanah tidak sesuai dengan fakta hukum yang sebenarnya terjadi di lapangan.

Sejauh ini, muncul perdebatan dan kendala dalam melakukan redistribusi tanah dalam rangka penguatan hak atas tanah bagi petani penggarap karena perbedaan persepsi mengenai pengertian dan kewenangan pengelolaan tanah negara bekas HGU PT. BMS antara Kantor Pertanahan Kabupaten Rejang Lebong dan Bupati Kabupaten Rejang Lebong, dan ini dibutuhkan solusi untuk duduk bersama menemukan titik temu, apa yang seharusnya dilakukan untuk masyarakat. Menyamakan persepsi mengenai pengertian dan kewenangan pengelolaan tanah menjadi penting agar persoalan yang sudah berlarut bisa segera diselesaikan. Tanpa penjelasan yang komprehensif atas status dan kedudukan tanah tersebut akan mengaburkan banyak pihak dalam menyikapi tanah bekas hak tersebut.

\section{Daftar Pustaka}

Arianto, T, dkk 2015, "Kajian Hukum Tentang Keberadaan Hak Prioritas Dalam Penyelesaian Masalah Pertanahan", Hasil Penelitian Strategis, Sekolah Tinggi Pertanahan Nasional, Yogyakarta.

Departemen Pendidikan dan Kebudayaan Propinsi Bengkulu, Aspek Geografi Budaya dalam Wilayah Pembangunan Daerah Bengkulu, Bumi Aksara, Jakarta.

Erwiningsih, W 2009, Hak Menguasai Negara Atas Tanah, Total Media, Yogyakarta.

Gunawan 2013, "Redistribusi Tanah (Antara Harapan dan Kenyataan), Jurnal Pertanahan, Volume 3 Nomor 2, Novemver 2013.

Harsono, B 1999, Hukum Agraria Indonesia, Sejarah Pembentukan UUPA, Isi, dan Pelaksanaan Djambatan, Jakarta. , 2008, Hukum Agraria Indonesia, Sejarah Pembentukan Undang-Undang PokokAgraria, Isi dan Pelaksanaannya, Jilid 1, Edisi Revisi, Cetakan Keduabelas. Djambatan, Jakarta.

Marbun, S 2015, "Peta Sengketa dan Konflik Perkebunan dan Tanah Negara: Upaya Penyelesaiannya", Paper disampaikan dalam diskusi Lingkar Belajar Bersama Reforma Agraria (LiBBRA) di STPN Yogyakarta o3 Juni 2015.

Pemerintah Propinsi Daerah Tingkat I Bengkulu 1990, 22 Tahun Propinsi Bengkulu 18 November 1990, Badan Perencanaan Pembangunan Daerah Propinsi Bengkulu, Bengkulu.

Salim, M. Nazir 2014, "Membaca Karakteristik dan Peta Gerakan Agraria Indonesia”, Jurnal Bhumi, No. 39 Tahun 13, April 2014.

Sanusi 1998, "Pengelolaan Tanah Negara dan Permasalahannya di Kotamadia Semarang", Tesis pada pada Jurusan Ilmu Sosial, Universitas Gajah Mada, Yogyakarta.

Sarjita, dkk 2013, "Gugatan atas Penetapan Tanah Terlantar di Provinsi Banten”, Hasil Penelitian Sistematis STPN 2013, STPN Press, Yogyakarta. , 2012, Tanah Negara, STPN Press, Yogyakarta

Sitorus, O dkk 2006, Pengelolaan Tanah Negara Bekas Hak Guna Usaha Perkebunan Besar Yang Berakhir Jangka Waktunya Di Propinsi Sumatera Utara, Laporan Penelitian. Sekolah 
Tinggi Pertanahan Nasional, Yogyakarta. Soesangobeng, H 2012, Filosofi, Asas, Ajaran, Teori

Hukum Pertanahan dan Agraria, STPN Press, Yogyakarta.

Sugara, B 2009, "Pelaksanaan Pensertipikatan Tanah dalam Rangka Penguatan Hak Atas Tanah di Kecamatan Plaju Kota Palembang”. Tesis pada Universitas Diponegoro.

Suhariningsih dkk 2008, "Alternatif Model Pengelolaan HGU (Perkebunan) Berbasis Land Reform dan Corporate Social Responsibility Menuju Reforma Agraria”, Hasil Penelitian Hibah Bersaing dari Proyek DIKTI Periode XV-1 Tahun Anggaran 2008/2009.

Sumardjono, M S.W 2008, Tanah dalam Perspektif Hak Ekonomi, Sosial dan Budaya. Buku Kompas, Jakarta. , 2009, Kebijakan Pertanahan Antara Regulasi dan Implementasi. Cetakan VI. Grafika Mardi Yuana. Bogor. , 2010, Tanah Untuk Kesejahteraan Rakyat. Fakultas Hukum Universitas Gajah Mada, Yogyakarta.

Zulkarnaen, A 2015, "Peningkatan Status Tanah Hak dalam Rangka Pembukaan Tanah Negara Menjadi Hak Milik Atas Tanah Tambak di Desa Diolo", Skripsi pada Fakultas Hukum Universitas Hasanuddin, Makassar.

\section{Online}

Bank Dagang Negara. https://id.wikipedia.org/ wiki/Bank_Dagang_Negara, diakses pada tanggal 20 April 2016, pukul 21.25 WIB.

BPS Kabupaten Rejang Lebong 2015, Statistik Kecamatan Kotapadang 2015, Merdeka. Curup. diunduh melalui http:// rejanglebongkab.bps.go.id/webbeta/backend/ pdf publikasi/Kabupaten-Rejang-LebongDalam-Angka-2015.pdf pada tanggal 29 Januari 2016, pukul 21.14 WIB. , Provinsi Bengkulu Dalam Angka 2015. Merdeka. Curup. diunduh melalui http:// bengkulu.bps.go.id/webbeta/website/ pdf_publikasi/Provinsi-Bengkulu-DalamAngka-2015.pdf pada tanggal 29 Januari 2016, pukul 21.14 WIB.

Bahanan, Sugian, "Pengembalian Hak Ulayat Suku Tengah Kepungut”. Diakses melalui http:// www.akar.or.id/index.php/2013/01/18/ pengembalian-hak-ulayat-suku-tengahkepungut/ pada tanggal 20 Februari 2016 pukul 22.15 WIB.

Soesangobeng, Herman, dkk. 2012. "Laporan Akhir Tim Pengkajian Hukum Tentang Pengelolaan Tanah Negara Bagi Kesejahteraan Rakyat". Di unduh melalui http://www.bphn.go.id/data/ documents/pkj_2012 - 3.pdf pada tanggal 23 maret 2016, pada pukul 18.20 WIB. 